\title{
EXTENSIVE READING FROM STUDENTS’ PERSPECTIVE
}

\author{
Adwind Abrar ${ }^{\left.a^{*}\right)}$, Atti Herawati, M.Pd ${ }^{\text {a) }}$, Tina Priyantin, M.Pd ${ }^{\text {a) }}$ \\ a) Universitas Pakuan, Kota Bogor, Indonesia \\ *)e-mail korespondensi: adwinda123@gmail.com
}

\section{Riwayat Artikel}

diterima 23 November 2021 direvisi 11 Desember 2021 disetujui 30 Desember 2021

\begin{abstract}
.
Extensive reading is broadly known as reading for enjoyment and is beneficial for EFL students. However, nowadays, the growth of technology has become a matter for students to be reading less than they should be. Thus, this research focused on the online extensive reading as the course program the students had experience in Pakuan University to find out their perspective. The respondents were 15 students from sixth-semester students who had experienced the Online Extensive Reading subject. The research was conducted by using qualitative method and using questionnaires and one-on-one interviews as the instruments. Data collected were separated into three indicators, which included the learning process, students' skills improvement, and personal factors. Based on the result, the students' perspective on the Online Extensive Reading helped them improve, especially in vocabulary gained, reading interest and reading comprehension. On the other hand, most students perceived that the learning process was effective for them to learn in this Online situation. However, they suggested that they needed more virtual meeting sessions instead of using chat forum to discuss or share. Furthermore, there were a few students that didn't feel the effectiveness of the Online Extensive Reading because they had a problem in their personal characteristic such as, procrastinating, unmotivated to read, unmanageable time, and their lack of reading interest.
\end{abstract}

Keywords: extensive reading, online learning, online teaching

\section{EXTENSIVE READING ONLINE DARI PERSPEKTIF MAHASISWA}

\begin{abstract}
Abstrak. Extensive reading umumnya di kenal sebagai reading for enjoyment dan menguntungkan untuk mahasiswa EFL. Namun, saat ini, perkembangan teknologi menjadi masalah bagi mahasiswa untuk membaca kurang dari yang seharusnya. Oleh karena itu, penelitian ini berfokus pada Extensive Reading sebagai matakuliah yang dialami mahasiswa di Universitas Pakuan untuk mengetahu perspektif mereka. Respondennya adalah 15 mahasiswa semester 6 yang telah mengikuti mata kuliah Extensive Reading Online. Penelitian ini dilakukan dengan menggunakan Teknik kualitatif dengan menggunakan kuesioner dan wawancara sebagai instrumennya. Data yang dikumpulkan di pisahkan menjadi tiga indikator, meliputi proses pembelajaran, peningkatan kemampuan siswa, dan faktor pribadi. Berdasarkan hasil yang di peroleh, perspektif mahasiswa mengenai Extensive Reading Online ini, membantu mahasiswa meningkatkan kemampuannya dalam Bahasa Inggris, terutama dalam memperoleh kosakata, minat membaca dan pemahaman membaca. Disisi lain, Sebagian besar siswa merasa bahwa proses pembelajaran yang mereka dapat efektif dalam situasi online. Namun, mereka menyarankan bahwa mereka membutuhkan lebih banyak pertemuan virtual dibadingkan menggunakan forum diskusi. Selain itu, ada Sebagian kecil mahasiswa yang belum merasakan efektifitas dari pembelajaran Extensive Reading Online karena memiliki masalah pada karakterisitik pribadinya, seperti suka menunda-nunda, tidak termotivasi untuk membaca, waktu yang berantakan, dan kurangnya minat membaca.
\end{abstract}

Kata Kunci: Extensive reading, belajar online, mengajar online

\section{PENDAHULUAN}

In the educational life, EFL students are easier to understand the reading content which is written in students' mother tongue than written in other language. New vocab, different structure, the meaning of the texts are things to face for EFL students, whereas reading has crucial role in educational life to improve language skills (Al-Nazhari, 2016). Another thing to face for EFL students is the growth of technology. It becomes the matter for distracting students' attention to be readingless than they should be (Echnique et al., 2016). By the problems mentioned, experts have agreed that extensive reading (ER) could be the cure for such obstacles the EFL students have. Studies have proven that ER is the key to achieve higher reading proficiency (Krashen, 1993).
ER is much beneficial for EFL students to improve their language skill for example, ER could improve on attitude and motivation to read (grabe 2009); Promotes reading rate (stoller, 2015); reading fluency (Belgar and Hunt 2014); Vocabulary gain (Suk's 2016) Writing ability (Mermelstein, 2015). Furthermore, ER has 10 principles to be considered based on Day and Bamford (2002), there are: the reading material is easy; a variety of reading material on a wide range of topics must be available; Learners choose what they want to read; Learners read as much as possible; The purpose of reading is usually related to pleasure, information and general understanding; reading is its own reward; reading speed is usually faster rather than slower; reading is individual and silent; teachers orient and guide their students; and the teacher is a role model of a reader. 
Furthermore, ER can be implemented not only for offline activities but also for online activities, since the students have a strong belief concerning the effectiveness of the internet as valuable, useful and engaging, students are willing to endure the challenges and difficulties of online reading (Coiro, 2012). in the online situation, there are instructions required to be implemented effectively for teacher in teaching online, which are learning session, course design, interaction among students, and instructor preparation and support (wiest 2012). Not only that, Boyd (2004) said that there are four sets of factors for students to be successful in online learning situation. They are technical factors, environmental factors, the characteristics of students and learning characteristics.

From the texts mentioned above, the writer focused this study on the students' perspective about the course program (ER Online) the students had at their sixth semester in Pakuan University. This study focused on the learning process, students' skills improvement, and personal factors. Thus, this research might help lecturers develop more proper, interactive and attractive activities for students in teaching online ER because knowing students' sight has the same proportion to be considered to develop the teaching plan.

\section{RESEARCH METHODOLOGY}

This research applied descriptive qualitative method that is designed to describe provided information toward opinion or experiences of the students in Online Extensive Reading as the course program they had experienced. In addition, the data were collected using triangulation which use different techniques to gain the data. In this study, the writer used questionnaire and one-on-one interview. The respondents of the research were 15 students from 6th semester English students in Pakuan University. the writer used convenience sampling to get the respondents willingly join to this study.

In this online situation, the questionnaire was created using online form by Google. The questions on this form were open-ended question that related with the limitation focuses the writer had chosen. Then, it distributed to the respondents through WhatsApp. In conducting the interview session, each respondent was allowed to choose their own schedule to do the interview in a week. The respondents were asked not only based on the questions on the instruments but also some direct questions that the writer asked during the session. This session held in order to get in-depth information about their perspective toward Online Extensive Reading.

\section{DATA DESCRIPTION}

\section{A. Data from Questionnaire}

The questionnaire was created using Google form and distributed online through WhatsApp group the writer made. This questionnaire contained 18 open-ended questions and it was divided into three indicators which are the learning process, students' skills improvement, and personal factors.

1) Learning Process

Question number one was about the activities the students had experienced in the online extensive reading. The students answered that they were reading the fiction and nonfiction books, academic books, reading journals, articles, reading $\log /$ book $\log$, essays, book reports, book talks, and posting the tasks. In the next question, the students mentioned the platform they used during Online Extensive Reading and how the platform was. The students used the LMS, Zoom, WhatsApp, Facebook, YouTube, PowerPoint and websites. Based on the students' experience, those platforms were effective and efficient to use and help students to understand the course at ease. In this course, the lecturers still provided the sources of the reading material in the form of links and PDFs in the LMS. So, based on the result, the students could choose whether they wanted to use the provided one or they could find the book by themselves.

Moreover, the writer asked about the tasks they had in Online Extensive Reading. They got reading log or book log, book reflection, book form, book talk or presentation, book review. Eight of 15 students said that the tasks were easy enough to be done if the students read properly. However, others said that there were some points that they felt difficult at or to do, such as reading journal and academic book, finding the reading material, managing time, even understanding the tasks itself. Furthermore, based on the finding, the lecturers gave feedbacks to review and re-explain the discussion and the tasks the student had. The feedback itself was given during virtual meeting that were held once after two or three meeting. Moreover, the students were provided with the discussion forum from LMS.

\section{2) Students' Skills Improvement}

In this indicator, the writer started with the question that asked about their reading interest and comprehension. Then, 12 of 15 students answered that they gained improvement. Other than that, this course helped students to help their future research and get used to reading journal even though the reading materials were difficult. Besides, the other students did not feel if there were improvements in their reading comprehension and interest. It was caused by their low reading interests, online situation and lack of vocabulary.

On the other hand, 13 of 15 students gained new vocabularies in this course. It was because they searched the meaning of the words they did not know. By the vocabularies they gained in Online Extensive Reading, there were only 11 students who perceived that they got improvement in their writing skills. However, the other students did not feel any improvement because there was no activity that emphasized their writing skill. Moreover, the last question asked about their speaking skill, and the result was 8 of 15 students perceived that they only got a little improvement, and the other 7 students did not feel any improvement in their speaking skill. It happened since the students were asked more to read than to speak.

\section{3) Personal Factors}

The first question in this indicator asked the student's condition of their place or home for doing online learning. 12 of 15 students answered that their home condition was completely supportive for Online Extensive Reading activities like nothing bothered, having nice workspace and 
proper devices to do Online Learning. However, others answered that their conditions were not proper to do online learning, for example, having the noisy situation, having the signal problem, and having another works to do at home.

Students were also asked about the preparation they did before doing Online Extensive Reading class. 13 of 15 students said that they prepared themselves before the class started, from the appearance, reading the material, until the devices. In the online learning situation, it always deals with the signals problem. Therefore, students were asked about the condition of the signal and the device they were using during Online Extensive Reading. 9 of 15 students had signal problems and have electricity constraints, but they could fix them, whether moving to another place or using two different providers.

Other than that, family members could be the factor of successful online students. 14 of 15 students said that they were supported by their families. Their family just facilitated the students with devices, no noises, also motivated the students by giving some snacks for instance. Lastly, the writer asked about their reading schedule in this course. There were different situations also different schedules for themselves for reading for example, when having the task, one-day onechapter, free time, 2 hours per day, weekend, and one/threeday one journal.

\section{B. Data from Interview}

An interview is the last instrument to gather the data in this research. The students who had answered the questions from the questionnaire agreed to do a one-on-one interview using zoom meeting. The interview was held in order to get more and deeper information from the students after having Online Extensive Reading. There were eight questions in this session which are divided into three indicators: learning process, students' skills improvement, and personal factors. The description can be seen as follows:

\section{1) Learning Process}

In this indicator, firstly the writer asked about the activities that were fun and boring for them. The answers are varied. The most answer is finding and choosing the topic they want, also because they have their own goal which was for doing their research paper. another answer is a book sharing or discussing sessions through video conference was fun to do. It was like they could share what and why about the book they read, and get feedback from others. One student answered that making the tasks was fun, such as analyzing journals, making sticky notes, so she could highlight the important or interesting point from the topic.

Another student answered that there was no fun at all because this student did not like the kind of reading material the lecturer had chosen but this student knew that what she "had" to read was useful. Moreover, the boring activities they had experienced in Online Extensive Reading was the reading itself. It was because their reading materials were difficult, numerous unfamiliar academic and formal words.

Students also perceived that making reading log or log book, not interested to read, and lack of interaction made them bored. Even though the students had boring feeling, the lecturers gave them motivation to cheer the students up by asking them. So, there were many kinds of motivation the lecturers did based on the students' answers such as, having zoom meeting and telling them the benefits of reading, levels of reading, telling the lecturers' experience about the book, showing the lecturers interests in the books that the students read, giving nice words, recommending some books, and asking about their reading progress. Furthermore, the reading $\log$ or log book became one of the motivations to keep the students reading, because it was like their target to read.

The last question in this indicator was asking about the students' perception of the effective system in Online Extensive Reading. 7 of 15 students answered the system was good enough. However, most of the students answered, that they needed more zoom meetings or video conference sessions to do discussion or book sharing or book club. The others suggested to change from reading journals to read any reading material students want and change the log book into video reviewing. On the other hand, a student also said that there was no problem with the system or lecturers, but it was about the students who need more advises to increase their reading interests.

In the middle of the interview session, the writer asked another question out of the script. It was "are you enjoying reading the books?". Surprisingly, 11 out of 15 students answered that they enjoyed their reading because they had goals and they got a lot of benefits from their reading. However, the other four students answered that they were not enjoying at all because of the genre of the reading materials, the reading materials were difficult to find or to understand, and because the reading logs. Another additional question was asked to some students about was the lecturer a good model for the reading itself and they answered yes

\section{2) Students' Skills Improvement}

Based on the answers, Online Extensive Reading affected more on students' vocabularies gain and new knowledge. The effect caused the students through the genre of their reading and some additional activities they had in the Online Extensive Reading. There are only three of 15 students answered that they just got a little effect during this Online Extensive Reading. However, Online Extensive Reading still has an effect on the students. Another question was asking about the activities that were more effective to them. The most answer went to the reading activity itself, followed by reading log, discussing or sharing session, analyzing the book, and making a review video.

\section{3) Personal Factors}

The last two questions in the interview session were about the students' personal factors. The students asked about their problem during the class and how they face it. There are only two students that did not have any trouble during Online Extensive Reading subject. Other students' problems came from different factors, such as, the connection and electricity problem. The students moved away from his place that was located $20 \mathrm{~km}$ away to his friend house from his place that located $20 \mathrm{~km}$ away to his friend house. 
three students answered that their problem was because of their laziness and procrastinating unmanageable time and uninterested to read, and boredom with the book. Personal factors also came from the wrong group partner, the printed book, and unclear instruction. However, even though they had problems during online learning they knew how to fix their own problem, such as forcing themselves to keep reading.

\section{DATA ANALYSIS}

From the first indicator, which is the learning process of the Online Extensive Reading, it was analyzed using some of Day and Bamford (2002) principles. The obvious principle that this Online Extensive Reading use is learners chose what they wanted to read and the reading material on a wide range of topics must be available. These first two principles are matched with what the research found. The lecturers provided the reading materials using websites that let the students chose what they wanted to read or just found the books by themselves. On the other hand, the lecturers limited the type of reading the students must read that made students hardly read the reading material they had chosen. Whereas, the reading material should be easy is the first principle of extensive reading. Amazingly, even if the reading material the students found was difficult and some of them answered it was boring, but there were only 4 out of 15 respondents that did not enjoy their time in the Online Extensive Reading. Their reason was because these students did not like the type of the reading material, the subject was difficult, there had no reading interest. It is shown as Arnold (2009) found, the students who purposely sought the higher-level reading material had gained the self-motivation and self-confidence to challenge themselves.

Besides, even if they felt bored with the reading material, the writer found that the focus of this Online Extensive Reading subject was that the students read as much as possible and the reward was the reading itself. Those focuses are the other two principles of Extensive Reading (Day and Bamford, 2002). It could be seen by how the lecturers motivated the students by giving some motivational words and becoming the role model of a reader because the student learnt the teacher or lecturer as the model of a good reader (Day and Bamford, 2002). Moreover, the tasks the lecturers gave, for example, in the logbook/ reading log, only two students answered that it was boring activity but the other answered it was one of motivations the lecturers gave to keep reading. Furthermore, the students had another reading target that makes them keep reading, it is their research proposal. As Arnold (2009) said that this indicated that students grow their motivation and self-confidence. Moreover, this finding is in line with Day and Bamford (2002) principle that teachers may ask students to complete follow-up activities based on the students reading while respecting the students' reading experiences and extend them in interesting and useful ways.

Based on the students' perspective, the learning process of ER in the online situation was held effectively. Based on Wiest (2012), there were approaches to be effective in the online situation and this Online Extensive Reading had implemented them. Firstly, the course design, multiple methods of content and exploration including synchronous and asynchronous learning activities had been applied. There were YouTube videos about reading to motivate the students, the lecturers provided online library to explore, using Zoom for doing virtual meeting, and discussion forum had been designed well. Zoom meeting was very useful in this online situation for ER to create interaction among participants. As Tee and Karney (2010) found in their research that providing students opportunities to share their experiences, views, and opinions develops their trust and decision. The writer believes that the lecturers have designed this course properly. However, the students said that they need more meeting virtually instead of using chat forum for discussion.

A problem in the online learning is also found problem from the devices and the electricity the students' have, but they got over it. It might not be a serious problem for the personal factor in online situation, but the writer thought that it had been considered why the virtual meeting was only done for 3 times or more in this semester. Another personal factor that became a trouble for only three students was from their personal characteristic, which was one of the factors that contributed for success online students (Boyd, 2002). It could be seen from their answers, like procrastinate just because of not being watched and the other two students answered that they just had no reading interest. It could be defined that these three students were not motivated to read in online learning situations because to be successful online students, they should have high self-motivated and self-disciplined (Engineering Outreach, 2001). It is shown from the other respondents that their reading interests were improved, even if the reading materials were difficult to read. Other than that, they did not have any problems with their personal environment. Their families were supportive, they did prepare themselves before the class started, their devices or connection problem were fixed by their own way and, they scheduled their reading time. As Roper (2007) said that developing a schedule that designates specific times will help students to be successful as online learners.

Moreover, while the factors of successful online students positively appeared among students, it helped them to get their goal and improvement. The improvement that barely could be seen is the vocabularies enrichment they had from their reading. 11 students answered that their writing skill also improved because they gained new vocabulary and logbook task they had. On the other hand, the other four students answered that they writing skill didn't improve because there was no emphasis for their writing skill. It is in the same line as Suk (2016) claimed that the evidence of ER is helping the students in vocabulary gain. Furthermore, 13 students' reading comprehension and interest were improved because they felt reading academic book, non-fiction, journal and article had a lot benefits, and they also knew that there was a responsibility to read as a student. It is in line with Chen et. Al (2013) concluded that with freedom to select the reading material base on their interest and associated with positive attitude, the learners achieved not only substantial 
improvement in their reading comprehension, but also had greater enrichment in vocabulary.

\section{CONCLUSION}

From the findings, the writer concluded that from students' perspective, this Online Extensive Reading helped them to increase their reading interest and comprehension. Not only that, they also gained a lot of new vocabularies and knowledges from their reading material. The task, especially the reading log, was helpful for the students to keep reading even if they felt forced to read. However, at the end, they got used to read the book that they had chosen freely and think was difficult. They read a lot compared to their daily activity before. This Online Extensive Reading had been effectively implemented the principles of Extensive Reading (Day and Bamford, 2002) and the online learning effective approaches (Wiest, 2012).

The students perceived that this course's learning system was well designed so did the lecturers in charge performed well. However, the students still wanted to have more virtual meetings using zoom, so they could discuss, share their book, and meet each other virtually, rather than using LMS only. Moreover, students in this Online Extensive Reading, had applied the factors of successful online students, such as supportive family or significant other, self-motivated, prepared before the class, and understand the devices and the platform used. On the other hand, the signal problem always happened in the online situation. Surprisingly, it did not become a big problem for students in the Online Extensive Reading, because they found a way to fix them. Lastly, the problem also came from the personal characteristic of the students themselves, such as, procrastinating, and still not be interested to read.

Therefore, there are several suggestions as the reflection related to the study. Firstly, for lecturers who are dealing with Online Extensive reading, the writer suggests to add more virtual meeting session with interactive activities such as book sharing in the future Online Extensive reading. The last suggestion is for the students to start managing time, being disciplined, and responsible to their reading.

\section{REFERENCES}

Al Nazhari, H., Delfi, S., \& K, S. (2016). A study on english reading habits of students of english study program of riau university. Jurnal Online Mahasiswa Fakultas Keguruan Dan Ilmu Pendidikan Universitas Riau, 3(2), 1-8. Retrieved from https://jom.unri.ac.id/index.php/JOMFKIP/article/vie w/10027

Arnold, N. (2009). Online extensive reading for advanced foreign language learners: An evaluation study. Foreign Language Annals, 42(2), 340-366. https://doi.org/10.1111/j.1944-9720.2009.01024.x

Blocher, J. M., Sujo De Montes, L., Willis, E. M., \& Tucker, G. (2002). Online learning: Examining the successful student profile. Journal of Interactive Online Learning, $1(2), 1-12$.
Carlson, J. A. (2010). Avoiding traps in member checking. Qualitative Report, 15(5), 1102-1113. https://doi.org/10.46743/2160-3715/2010.1332

Chen, C. N., Chen, S. C., Chen, S. H. E., \& Wey, S. C. (2013). The effects of extensive reading via e-books on tertiary level EFL students' reading attitude, reading comprehension and vocabulary. Turkish Online Journal of Educational Technology, 12(2), 303-312.

C-Ferre, Heather G. Wiest, Lynda R. (2012). Effective online instruction in higher education. Quarterly Review of Distance Education, 13(1), 11-14.

Day, R. 2015. Extending Extensive Reading. Reading in a Foreign Language, 27(2), 294-301.

J.Yamashita1, Y. j. (2013). Effects of extensive reading on reading attitudes in a foreign language. Reading in a foreign language, 25(2), 248-263. Retrieved from: http://ezproxy.shsu.edu/login?url=http://search.ebsco host.com/login.aspx ?direct $=$ true $\& \mathrm{db}=\mathrm{ofm} \& \mathrm{AN}=9156$ $5525 \&$ site $=$ eds-live $\&$ scope $=$ site

Mikeladze, T., \& Iakob, T. (2016). Reading. 1968(January), $22-28$.

Moore, J. L., Dickson-Deane, C., \& Galyen, K. (2011). ELearning, online learning, and distance learning environments: Are they the same? Internet and higher education, 14(2), 129-135. https://doi.org/10.1016/j.iheduc.2010.10.001

Prowse, P. (2002.) Top ten principles for teaching extensive reading: A response. Reading in a foreign language, $14(2)$.

Dornye, S. (2007) Research methods in applied linguistics. Oxford University Press

Smadi, O., \& Linguistics, A. (2013). The effect of an online extensive reading instructional program on jordanian eleventh grade atudents ' Proficiency in English, 4(12), $170-188$.

Wijayanti, S. (2020). Indonesian students' reading literacy, $390 \quad$ Icracos 2019, 61-65. https://doi.org/10.2991/icracos-19.2020.13 